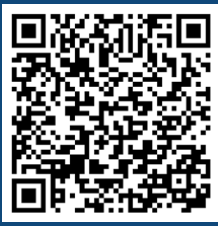

Keywords:

Dead wood

Fine woody debris

Litter

Organic matter

Historic: Received 25/08/2019 Accepted 10/12/2019

+Correspondence: mateus.sanquetta@gmail.com
Greyce Charllyne Benedet Maas'a , Carlos Roberto Sanquettalb, Renato Marques ${ }^{\text {lc }}$, Sebastião do Amaral Machadold, Mateus Niroh Inoue Sanquettale+

\section{QUANTIFICATION OF CARBON IN FOREST NECROMASS: STATE OF THE ART}

MAAS, G. C. B; SANQUETTA, C. R.; MARQUES, R.; MACHADO, S. A.; SANQUETTA, M. N. I. Quantification of carbon in forest necromass: state of the art. CERNE, v. 26, n. I, p.98-108, 2020.

\section{HIGHLIGHTS}

IPCC and FAO report the lack of data concerning carbon stocks in forest necromas.

The use of ambiguous terminologies is recurrent in related studies.

We present a new classification for avoiding misunderstanding..

Specific sampling methods can improve the accuracy of local reports..

\section{ABSTRACT}

Necromass play a significant ecological function, including the deposition of organic matter, which is essential for carbon cycling in forest ecosystems. Despite the devoted attention to the role of forest necromass into the global carbon cycle, international organizations such as IPCC and FAO have reported the lack of compatible data concerning the carbon stocks in forest necromass among different regions. This paper reviews the terminologies and sampling methods regarding the quantification of carbon stock in forest necromass. Volume, biomass and carbon content determination methods were examined into the literature and then notably in Brazil. We address the problems associated with sampling methods and spatial distribution in related studies. Conflict in nomenclatures, components and diameter threshold confound the comparison of regional results. Meanwhile, we present a standard terminology for similar studies. Coarse woody and non-woody (litter) necromass are frequently computed, although fine woody necromass stands ignored in most studies and reports. Finally, we provide recommendations on specific sampling and measurement methods, taking into account necromass size and spatial pattern for both necromass and litter. 


\section{INTRODUCTION}

The Intergovernmental Panel on Climate Change (IPCC) defines five carbon pools in forest ecosystem: aboveground biomass, belowground biomass (roots), soil organic matter, deadwood, and litter. The latest two fits in the definition of necromass (IPCC, 2006).

Forest necromass consists of dead plant components, including fine litter, dead fallen logs, and branches on the ground, standing dead trees, stumps and dead roots (IPCC, 2003; Pearson et al., 2005). Several studies highlight the role of necromass in forest ecosystem functioning. Dead plants provide habitat for many species (Stokland et al., 20I2) and influence on geomorphological, an important component of hydrology from river systems and channels (Harmon et al., 1986; Kennedy and Woods, 2012). The raised discussion on climate change as related to the global carbon cycle has brought the importance of necromass in carbon stocks and greenhouse gas emissions.

Necromass represents around 10\% of stored carbon in worldwide forests (FAO, 2010) and its decomposition is the dominant process in soil carbon stock balance (Berg and McClaugherty, 20I4; IPCC, 2006). Moreover, the soil contains $45 \%$ of stored carbon in worldwide forests (FAO, 2010).

In the 2010 Global Forest Resource Assessment report (FAO, 2010), 180 countries (representing 94\% of the world's forests) reported carbon stocks in forest biomass. The percentage of reporting countries for carbon stocks of litter has fallen to $78 \%$. Still, the number of countries reporting carbon stocks in deadwood is even smaller, 72 countries (6I\% of the world's forests).

According to the Food and Agriculture Organization of the United Nations (FAO, 20I0), most countries have no national data and uses default values from IPCC Good Practice Guidance for Land Use, Land Use Change, and Forestry - LULUCF (IPCC, 2003). Data inclusion on deadwood in national forest inventories started recently, for most countries, it started from 2000 onwards (Woodall et al., 2009). In the Guidelines for Inventories of Greenhouse Gases published in 2006, the IPCC omitted the default values of carbon stock in deadwood due to the lack of available data. Meanwhile, the IPCC has evidenced incomplete values of carbon stock in the litter, due to different approaches when collecting data (IPCC, 2006).

This paper presents a review of terminologies and sampling methods for future studies addressing the quantification of carbon stocks in forest necromass. We discuss procedures in volume, biomass, and carbon content assessments in extensive literature and then especially in Brazil.
We highlight problems associated with necromass spatial distribution. Finally, we examine the inconsistencies between terminologies and methods adopted in similar studies among studies that address the quantification of necromass carbon.

\section{TERMINOLOGY}

The use of different terminologies for the same meaning and equal terms with different meanings is very common in forest necromass studies, such as dead organic matter (IPCC, 2006), dry mass of dead fine roots (Brunner et al. 20I3), above ground coarse necromass (Palace et al. 20I2), down woody materials (USDA, 20II), among others. This has hindered the definition of regional default values and the comparison within and between ecosystems. The terminological standardization in researches and projects on the dynamics of necromass and carbon stocks is a challenge to overcome.

The Guidelines for National Greenhouse Gas Inventories (IPCC, 2006) classifies the carbon pools in the LULUCF sector, for each land use category into biomass (above and below ground), necromass (including deadwood and litter) and soil (soil organic matter). The litter definition includes all non-living biomass from the diameter range, which is defined by every country ( 10 $\mathrm{cm}$ for example), it includes litter, fumic, and humic layers in different states of decomposition.

Litter terminology is commonly used when refereeing to dead material on the ground, mainly composed of leaves, bark, fruits, branches, flowers, etc. (Santos and Válio, 2002; Sato et al., 2004), i.e. the fine non-woody necromass. Some authors use "leaf litter" or "foliar litter" to distinguish leaves from the woody litter (Preston et al., 2006; Gessner et al., 20 I0). The "litterfall" terminology is used to refer to litter production, usually expressed in $\mathrm{Mg} \mathrm{ha}^{-1}$ per year (McClaugherty et al., 1985; Schlesinger and Lichter, 200I). The forest floor is used to denote the stocked litter $\left(\mathrm{Mg} \mathrm{ha}^{-1}\right)$ (McClaugherty et al., 1985; Schlesinger and Lichter, 200I). No common term has been adopted to describe the larger woody debris, i.e. dead trees and branches, leading in incompatible comparisons (Harmon and Sexton, 1996).

"Deadwood" is the IPCC official terminology to define all non-living woody biomass not accounted as litter, either standing or lying on the ground or belowground. Deadwood includes wood lying on the ground, dead roots and stumps larger than litter diameter range or any other limit diameter (IPCC, 2003). Such a term is also used by many researchers (Pasher and King, 2009; Sweeney et al., 2010). However, "coarse woody 
debris" (Keller et al., 2004; Knapp et al., 2005; Motta et al., 2006; Gough et al., 2007), "coarse woody detritus" (Busing et al., 2008; Harmon et al., 2008) and "dead woody material” (Köhl et al., 2008; Polo et al., 20I3) have been used.

There are also different termologias to define the position of any non-living material within a forest, i.e. standing or lying on the ground. Woodall et al. (2013) used "downed woody materials" (fallen logs) to distinguish lying down from the standing or suspended material, named as "standing woody material" (Harmon et al., 2013; Woodall et al., 2013). The snag is another terminology used to define standing dead trees, whereas log is used to fallen tree trunks (Janisch and Harmon, 2002; Nordén et al., 2004; Sweeney et al., 2010). The distinction of snags and logs depends on the inclination of the material, usually at a $45^{\circ}$ (Harmon and Sexton, 1996).

\section{SIZE OF PIECES AND MEASUREMENT RANGE}

Harmon et al. (1986) reported the different specifications when considering the size of necromass pieces, leading in results that cannot be compared. Harmon and Sexton (1996) concluded that for operational definition, it would be clearer to use the position (standing, downed, or buried in soil) and size or dimension (length and diameter) to define the terminology. For these authors, the terms "woody detritus" and "woody debris" could be used to include all forms of dead woody material above and below ground. Aboveground wood waste materials could be further divided into "coarse" $(10 \mathrm{~cm}$ at the large end and $1.5 \mathrm{~m}$ in length) and all smaller pieces are usually considered as "fine woody fractions". Coarse fractions can be divided into "standing dead material" (snags or standing dead) and "lying down material" on the forest floor, such as logs, dead and downed trees.

The IPCC (2006) suggests the minimum diameter of $10 \mathrm{~cm}$ or larger to classify any material as deadwood and every material with minor diameter should be considered as litter. Nevertheless, the IPCC mentions that each country may specify the minimum diameter to be considered for each component.

However, studies on litter usually do not consider fine woody residues or fine woody necromass. Thus, the default values presented in the Guide for National Greenhouse Gas Inventories (IPCC, 2006) related to carbon stock in forest necromass are incomplete.

Studies on fine necromass usually account leaves, reproductive material, and bark, but do not specify a threshold diameter in which dead branches and boles are included. Some authors consider a minimum diameter of I cm (Wood et al., 2005; Mota and Torezan, 20 I3), while others account for pieces with a diameter over $2 \mathrm{~cm}$ (Arato et al., 2003; Lima et al., 20 I0). Several studies did not mention the threshold diameter for dead branches inclusion in sampling. Woodall et al. (2009) revealed that deadwood inventories conducted by few countries specified a minimum diameter only for fine necromass.

Deadwood studies generally specify a larger threshold diameter for inclusion, usually ranging from 7 to $10 \mathrm{~cm}$. However, fine woody necromass is not accounted for as fine necromass (litter) or dead wood, and its quantification is simply neglected in these cases.

Fonseca et al. (20II) separated necromass between fine necromass (litter and deadwood minor than $2 \mathrm{~cm}$ of diameter) and coarse necromass (deadwood equal or larger than $2 \mathrm{~cm}$ of diameter). Pietro-Souza et al. (20I2) also classified the necromass using its diameter, considering as fine downed necromass pieces ranging from 2.0 to $9.9 \mathrm{~cm}$ of diameter and as coarse necromass those over $10 \mathrm{~cm}$. The authors did not include in their sampling the leaf litter, or logs and branches smaller than $2 \mathrm{~cm}$.

According to the field manual of the Brazilian National Forest Inventory - SFB (Serviço Florestal Brasileiro, 2014), the minimum diameter for the deadwood is $2.5 \mathrm{~cm}$ and the decomposition level have also to be considered. The length measurement of these pieces of branches and logs is not required. The litter sampling is performed by measuring the layer depth of deposited material on the ground, considering an angle of 90 degrees to the ground level.

The minimum length of the necromass pieces is considered for sampling only in a few cases. This system is used by the North American Forest Service (USDA, 20II), which states that the pieces must have at least 3 feet long if length (about to $0.90 \mathrm{~cm}$ ) to be sampled. In another study, Janisch and Harmon (2002) set a minimum length of I meter.

The trees structural characteristics should be considered when adopting the threshold diameter. There is notable diversity in Brazilian biomes. In the Amazon region, tree size can reach more than $2 \mathrm{~m}$ in diameter at breast height, while in Caatinga (dry Savanna) the vegetation is mainly composed of thin-low trees and shrubs (Giulietti et al., 2003).

Thus, the adoption of a single threshold diameter to classify the necromass can lead to inaccurate or biased estimates. An alternative to overcome this problem is the subdivision of woody necromass into two categories, 
from 2 to $10 \mathrm{~cm}$ and above $10 \mathrm{~cm}$. Differences in the definition of sampled components were indicated by Woodall et al. (2009) as one of the main factors that complicate the comparison of necromass estimates among studies and national reports. According to these authors, different objectives define the scope of each report (fuelwood evaluation, carbon stock quantification, biodiversity assessment, etc.), as well as budget constraints.

\section{PROPOSED TERMINOLOGY, SIZE OF PIECES AND MEASUREMENT RANGES}

We propose a terminology with the corresponding size of necromass pieces and the measurement range (threshold diameter) (Figure I). The proposed terminology reinforces the use of necromass as a standard term, composed of woody and non-woody material, excluding indistinguishable soil organic matter.

The terminology considers the material location (above and belowground), whether woody or not, downed or standing. The downed woody necromass may be further subdivided into fine and coarse according to its limit diameter. Besides, standing woody necromass can be classified into stumps or logs. Belowground necromass may be classified into fine and coarse. This proposal combines the given terminologies by Harmon and Sexton (1996) for woody debris and the size limits of previous researches, as suggested by the IPCC (2006).

Although the IPCC (2006) consider deadwood with less than $10 \mathrm{~cm}$ of diameter as litter, we recommend a separation in another class, named fine woody necromass for pieces with 2 to $10 \mathrm{~cm}$. This maintains consistency with other definitions given in related studies of litter components and prevents from neglecting this carbon pool in inventories. We recommend that the minimum diameter to compute the standing woody necromass be the same value for standing living trees so these measurements can be based on the same criterion. Although a given country can use a limit diameter smaller than $10 \mathrm{~cm}(\mathrm{e} . \mathrm{g} .5 \mathrm{~cm})$ in its inventory, it will be possible to estimate the necromass stock for any material over 10 $\mathrm{cm}$ diameter, if necessary.

IPCC (2006) suggest that only dead roots over 10 $\mathrm{cm}$ of diameter $10 \mathrm{~cm}$ of diameter should be accounted for. Harmon and Sexton (1996) recommend classifying as thick roots (dead coarse roots) those pieces with a diameter larger than $\mathrm{I} \mathrm{cm}$. These authors classify other materials as buried small fragments of unclear origin. We propose to keep I $\mathrm{cm}$ as the threshold diameter for dead roots and include those with diameters between 2 to 9.9 $\mathrm{mm}$ as fine dead roots. Following IPCC recommendation, we propose the classification of fine roots of less than 2 $\mathrm{mm}$ diameter as non-woody soil organic matter.

\section{METHODS TO INVENTORY NECROMASS CARBON STOCK}

Different sampling methods may be required to quantifying necromass in forests, once it may occur differently, such as dead standing trees, downed dead trees, large and small branches, stumps, dead roots, leaves, etc.

\section{Aboveground woody necromass}

The usual methods to determine carbon stock in forest necromass typically consider the volume $\left(\mathrm{m}^{3}\right)$ and basic density $\left(\mathrm{g} \mathrm{cm}^{-3}\right)$ for different stages of decomposition. Thus, necromass $(\mathrm{g})$ is obtained by the product between wood volume and density in each decomposition class (when this information is available).

The decomposition rate is negatively related with wood density (Chambers et al., 2000). Some authors, such as Chao et al. (2009) and Chave et al. (2009) suggest that wood density is the main wood property that controls and indicates the decomposition rate.

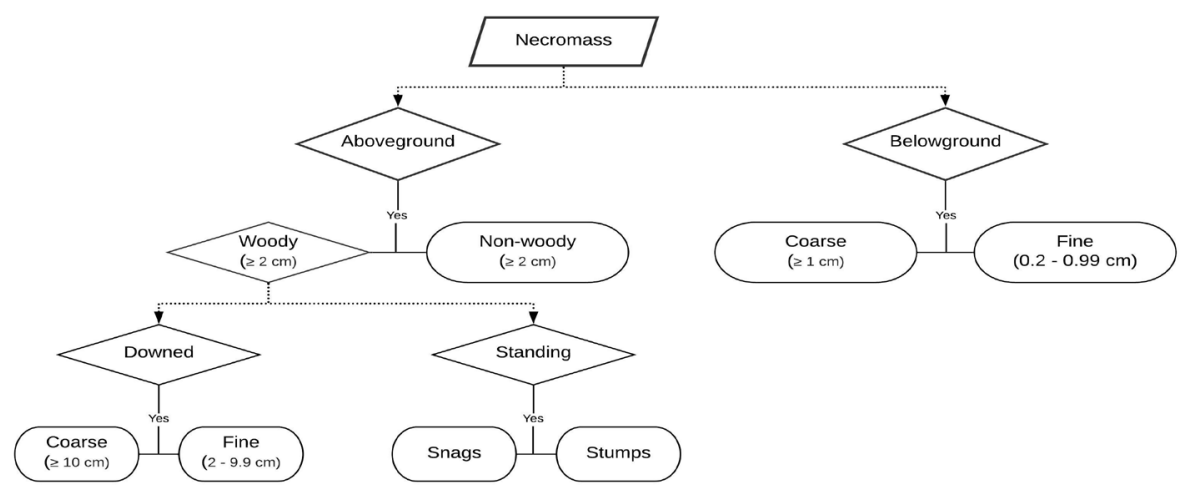

FIGURE I Diagrammatic representation of the proposed terminology and size limits of pieces for forest necromass inventory. 
However, the determination of basic wood density is not possible when pieces are highly decomposed. In this scenario, the use of apparent density or values described in the literature may be recommended (see Vieira et al. (20II) and Maas (20I5) for Brazilian Atlantic rainforest, and Keller et al. (2004) and Palace et al. (2007) for Brazilian Amazon rainforest). From these values, a weighting by area is performed to obtain the total necromass (IPCC, 2003). Therefore, the first step when estimating necromass and its corresponding carbon stock is the volume quantification.

The most widely used methods for estimating the volume of woody debris on the forest floor are: the intercepting line (e.g. Keller et al., 2004; Polo et al., 20I3; Aryal et al., 2014) and the fixed area plot (e.g. Fonseca et al., 20II; Mota and Torezan, 2013). IPCC (2003) suggests using the intercepting line method when the estimated amount of deadwood is approximately 10 to $15 \%$ of the aboveground biomass and the fixed area plot method when it is greater than 15\%.

\section{Intercepting line}

The intercepting line method applied in forestry was initially developed by Warren and Olsen (1964) to estimate the volume of residue after harvesting. Van Wagner (1968) adapted the Warren and Olsen (1964) method motivated by their involvement in the research on forest fires (Warren, 1990).

This method consists of arranging a line with predetermined length on the forest ground, followed by the diameter measurement of each woody piece that crosses the line (considering the threshold diameter). The lines arrangement varies from a single straight line, two lines in right angles (IPCC, 2003; Pearson et al., 2005), an equilateral triangle (Van Wagner, 1982) or lines starting from the center of a circular plot (USDA, 20II). Despite that, Van Wagner (1982) mentions that using lines in more than one direction may be useful to avoid bias due to the orientation of the pieces. The volume of necromass per hectare unit is estimated through the use of Equation I, in which the diameter of the piece and the line length are considered (Van Wagner, 1968), Where: $V=$ volume $\left(\mathrm{m}^{3} \mathrm{ha}^{-1}\right) ; D_{1}, D_{2}$ , ..., $D_{n}=$ diameter of each piece intersecting the line $(\mathrm{cm})$; and $L=$ the length of the line $(\mathrm{m})$.

To estimate woody necromass through the use of pieces volume, it is necessary to assign the decomposition class to each piece and collect samples for wood density determination. It is common to use three decomposition classes, which can be named: I)
$\mathrm{V}=\pi^{2} \cdot \frac{\left(\mathrm{D}_{1}^{2}+\mathrm{D}_{2}^{2}+\ldots+\mathrm{D}_{\mathrm{n}}^{2}\right)}{8 \cdot \mathrm{L}}$

solid, 2) intermediate and 3) highly decomposed (e.g. Pearson et al., 2005). Also, it is possible to find methods with five classes for this classification, which considers structural integrity, texture of the rotten portions, and color of wood, invading roots and branches and twigs (e.g. USDA, 20I I).

Several studies addressing the improvement of the intercepting line method were proposed (Woodall and Williams, 2007). Some studies proposed additional measures. Although the traditional method suggests measuring the diameter at the intersection point of the line, alternative methods also recommend the measurement of the diameter at the large and small end (e.g. USDA, 20I I). Nevertheless, even providing error reduction, the proposed changes may increase the time spent in sampling activities. A method modification called the planar intersect have the same theoretical foundations of the line intersect technique (Brown, 1974).

Fine woody necromass can also be sampled using the intercept line method. In this case, generally, only a fraction of the total length of the line is sampled (Harmon and Sexton, 1996). Sometimes the diameter of the smallsized pieces is not measured due to the exhaustive labor in measuring an elevated quantity of pieces with a caliper rule, for example. Rather, they are only counted by diameter classes using a template of known dimensions (Van Wagner, 1982; USDA, 20I I).

Finally, it is worth noting that even the intercept line method be simple; many questions arise concerning its use (Van Wagner 1982). There may be situations where a single curved part touches the same line twice or touches two sampling lines. In similar cases, we recommend following USDA (20II) and Brown (1974), because both specify alternatives to deal with such situations.

Fixed area plot

The size and shape of the plot are predetermined (Harmon and Sexton, 1996). Shapes can be square or fixed radius circles (Woodall et al., 2009). All necromass of a given diameter within the plot limit should be sampled. The diameter of the pieces is measured at the middle and/ or both ends (Ravindranath and Ostwald, 2008). It is also common to measure diameters every meter along the piece length (IPCC, 2003; Eaton and Lawrence, 2006). Variations of this approach are also used, depending on the volume sizing formula. In this method, it is necessary 
to classify the pieces into decomposition classes and collect samples to determine the wood density.

Fine woody necromass can also be measured in smaller portions of the fixed area. In this case, the weight is directly determined using a measured portable scale instead of resizing the volume. Samples are collected to estimate dry necromass (Harmon and Sexton, 1996). For example, woody necromass samples in small I x I m plots arranged within the sample plots used to measure coarse wood necromass were previously sampled (Eaton and Lawrence, 2006).

\section{Standing dead trees}

Sampling of standing dead trees is usually conducted simultaneously to the aboveground biomass inventory. In this case, DBH and tree height of standing dead trees are measured and their diameterheight relationship is assumed the same as living trees (Ravindranath and Ostwald, 2008). This arrangement between measurements of standing dead trees and living trees cannot be considered correct in all cases, since dead or suppressed trees tend to lose their crown. For example, if DBH is fixed at $15 \mathrm{~cm}$, not necessarily a diameter-height relationship equation should return the same value for a living and a dead tree.

Forest inventory activities are carried out for different purposes, and therefore not necessarily dead trees will be quantified. In this sense, some researchers proposed the measurement of dead trees from the intersection line used to measure the aboveground (fallen) wood necromass (Keller et al., 2004; Palace et al. 2007). Polo et al. (2013) sampled standing dead trees on a $50 \times 10 \mathrm{~m}$ plot measured along a $50 \mathrm{~m}$ long intercept line. Kirby et al. (1998) and Sweeney et al. (2010) measured dead trees along two $2 \mathrm{~m}$ lines on either side of the interception line, and Péllico Netto et al. (2018) used the Strand's method (Strand, 1958) for sampling standing dead trees and stumps.

\section{Non-woody necromass}

There are a few available methods to quantify non-woody stocked necromass on the forest ground. However, the use of a template (sample) of known size (e.g. Kleinpaul, 2005; Gough et al., 2007; Godinho et al., 2014) is the most frequent. Plots are established throughout the forest ground and all fine necromass inside the template is collected and weighted. Samples (or subsamples) are usually collected for moisture content determination and calculation of the dry necromass (Pearson et al., 2005). An alternative to measuring non-woody necromass on the forest ground is measuring the depth of the layer using a ruler (e.g. USDA, 20II; SFB, 20I4).

Measurement of non-wood necromass thickness can also be applied simultaneously to intercept line sampling (used for wood necromass) (Kostel-Hughes et al., 1998; Polo et al., 2013). The IPCC (2003) recognize this method as an alternative to sites where litter is well defined and deep (greater than $5 \mathrm{~cm}$ ). In this case, it is possible to fit a regression model to relate the layer depth to the stocked necromass per unit area. At least 10 to I5 plots are necessary to validate this method (IPCC, 2003).

The VCS (20I2) methodology for estimating carbon stock in the necromass suggest the measurement of necromass layer depth and density using a template with known dimensions, which is pressed against the layer. The collected sample is dried to estimate weight per unit volume (Kostel-Hughes et al., 1998). Reported density values can be alternatively used, but data may not be available for a few forest typologies (Chojnacky et al., 2009).

\section{Other material types}

The IPCC (2006) considers deadwood not only logs and branches but also dead stumps and roots with a diameter greater than $10 \mathrm{~cm}$ or a threshold diameter.

Thus, the weight of dead roots can be estimated using the diameter of dead trees (eg, Weggler et al., 20/2). However, root biomass and necromass estimation methods are scarce compared to aboveground biomass methods (Cairns et al., 1997; Harmon et al., 200I), mainly because their determination is highly expensive and time-spending (Resh et al. 2003).

According to Nordén et al. (2004), dead tree stumps are generally ignored in biomass inventories, although Woodall et al. (2009) observed that over $60 \%$ of the countries analyzed in their study reported this component. Woodall et al. (2009) pointed out that different number of measured components make necromass estimates unmatched across countries.

\section{Lack of data on fine woody necromass}

The fine woody is usually neglected in forest inventory activities, as early mentioned.

The use of small sample plots (eg $0.3 \times 0.3 \mathrm{~m}$ templates) and the measurement of layer depth is recurrent in related studies. Moreover, some studies have included logs up to $2 \mathrm{~cm}$ of diameter and coarse woody residues (generally over $10 \mathrm{~cm}$ of diameter). However, there is a gap between these two dimensions. 
Only $47 \%$ of the national reports explicitly evaluated fine woody necromass. We believe that fine woody necromass was accounted for non-woody necromass (Woodall et al., 2009).

The great variability on the spatial distribution of woody necromass implies the use of larger plots (at least $\mathrm{I} \times \mathrm{I} \mathrm{m}$ ) and higher sampling intensity than those frequently used for non-wood necromass measurements (often $0.3 \times 0.3 \mathrm{~m}$ ).

The use of larger plots and sample sizes for a simultaneous inventory of non-woody and fine woody necromass would greatly increase spent time in data collection. However, separately sampling of non-woody and fine woody necromass may be necessary considering the size and distribution of these variables.

The application of permanent plots may difficult the fine woody necromass sampling since their parts must be cut to include only pieces contained inside the plot boundaries. This activity becomes more difficult as the threshold diameter increase. An alternative to overcome this problem is the fine woody necromass measurement using the intercepting line method, which is similarly used for coarse woody necromass (diameter class count across the line (USDA, 20I I).

Decomposition classes and wood density determination

There are several rules for including parts in decomposition classes. The most common methodologies suggest classification based on wood appearance (SFB, 20I4). For example; solid, intermediate and highly decomposed (Pearson et al. 2005). Harmon et al. (1995) defined five classes, class I being the one in which the newest fallen logs had leaves and branches attached, while class 5 consisted of pieces in advanced deterioration stage, and in many cases, the wood could be scattered across the soil surface (Keller et al. 2004).

Besides, some methods are based on the difficulty of sinking a tool into the piece of wood (i.e. a saw or a knife) (Pearson et al., 2005). However, the comparison of both approaches is subjective and can lead to unreliable results. The methodology described by Harmon et al. (1995), Keller et al. (2004), and SFB (2014) classify the newly fallen pieces (i.e. with bark and attached branches) as class I, while the methodology proposed by Pearson et al. (2005) considers the pieces fallen for a long period, but with high density as belonging to class I. These authors also mention that decomposition rate is a function of species and diameter of the piece since are expected that pieces with larger diameters show a lower decomposition rate over a fixed period of time.

Wood density determination requires a representative sample number from each decomposition class. This involves cutting or sawing the parts, such activity demand time and requires the use of appropriate tools. For larger and high-density trees or poorly decomposed pieces of wood, the use of a chainsaw is crucial, which requires trained and equipped professionals. Besides, each sample should be identified by the state of decomposition and brought to a well-equipped laboratory where pieces should be available for wood density determination. Due to the difficulty of sampling deadwood to determine wood density for each forest typology, literature figures have been widely used (Polo et al., 2013; Aryal et al., 2014). However, such practice should be appropriate only in similar conditions. Addition, local characteristics may influence the number of pieces for each decomposition class, affecting the sample representativeness.

Eaton and Lawrence (2006) conducted a study in which $18 \mathrm{I}$ pieces of wood were sampled. This study was carried into a dry tropical forest in the state of Campeche, Mexico. A great variety of species were accounted for in 5 different decomposition classes. However, despite a large number of parts sampled, none were classified as class I, since all parts suffered some degree of decomposition.

There is a remarkable necessity for compilation and easy access to existing data on wood density among decomposition rates at different forest typologies. The development of a standardized and non-destructive methodology to obtain the density of woody necromass pieces remains a challenge (Brown, 2002). For this purpose, a penetrometer device (Pylodin) has been used in forestry for the indirect determination of wood density. The user inserts a steel pin with precise force and the penetration of the instrument indicates a depth inversely proportional to the wood density (Hansen, 2000). This tool is promising for fast and precise determination of deadwood density in the field at various levels of decomposition (Mäkipää and Linkosalo, 20I I).

\section{Necromass carbon fraction}

The carbon fraction is a non-dimensional parameter, which represents the proportion of carbon in dry biomass or dry necromass. The usual methods for estimating the carbon fraction in the woodare total dry combustion (Preston et al., 2006; Zhang et al., 20I I; Sanquetta et al., 2013) and chemical oxidation (Caldeira et al., 2008; Watzlawick et al., 20I2). Although, literature 
(Polo et al., 20I3) and the IPCC default values are widely used.

The carbon fraction varies depending on the degree of decomposition. Harmon et al. (2013) studied the carbon content of woody debris from 60 tree species in the Northern Hemisphere. These authors noticed that the carbon content varies according to tree rate, stage of deterioration, tissue type, and vertical orientation. This study found higher values in highly decomposed pieces compared to recently downed deadwood and living biomass. According to Harmon et al. (20/3), uncertainties associated with forest carbon inventories can be reduced by using specific detrital carbon values rather than assuming the single $50 \%$ value that is commonly practiced for living biomass.

\section{SAMPLE SIZE FOR NECROMASS INVENTORY}

Deadwood usually has a non-uniform distribution in the forest (Ducey et al., 2002; Pasher and King, 2009). The deadwood values do not present a normal distribution but tend to present a positive asymmetry. There are a higher number of plots with low or none amount of deadwood, and only a few plots show a great number of pieces (Harmon et al., 1986). It can be associated with the spatial pattern of the necromass, mainly for the coarse woody necromass.

The diameter distribution of wood necromass pieces usually takes a negative exponential form in natural forests (Ribeiro et al., 2012; Fonsêca et al. 2019). A high number of small-diameter pieces while higher diameters are observed in smaller quantities. This pattern matches the living trees diameter distribution in natural forests. Thus, in other environments, the diameter distribution of wood necromass pieces will naturally tend to approximate the diameter distribution of the living trees (e.g., assuming a diameter distribution similar to the normal distribution, in forest plantations, for example).

The sample variance associated with deadwood is elevated, requiring exhausting sampling for accurate and unbiased results (Harmon et al., 1986). For example, coefficients of variation below $50 \%$ of the average may require higher sampling intensity and larger sample unit sizes (Wollendorp et al., 2004).

In Brazil, the National Forest Inventory sampling grid is composed of equidistant points $20 \mathrm{~km}$ away. According to the field manual (SFB, 20I4), a denser grid may be required for special applications such as a representation of different vegetation types and regional strategies. Grids of $10 \times 10$ kilometers, $5 \times 5$ kilometers, and $2.5 \times 2.5$ kilometers are suggested for such purposes. For necromass sampling, the
Brazilian Forest Inventory manual indicates the use of two lines ( $10 \mathrm{~m}$ of length) intersecting at the center of the sampling unit for tree measurements (cross-shaped). However, Brazil still has a rustic experience in conducting necromass inventories and this method should be refined depending on the preliminary results of the national inventory. IPCC (2003) suggests a minimum length of $100 \mathrm{~m}$ when applying the intercept line method, generally divided into two $50 \mathrm{~m}$ sections placed at right angles across the plot center. No recommendation is provided regarding sampling intensity.

Harmon and Sexton (1996) suggest the use of fixed area plots of $\mathrm{I} \mathrm{m}^{2}$ due to the high variability in fine wood necromass. The authors also recommend the use of at least 10 plots for each sampled population. Still, regarding the sample intensity for wood density determination, IPCC (2003) and Pearson et al. (2007) recommend collecting at least 10 samples per decomposition class.

\section{CONCLUSIONS}

The used nomenclature when quantifying necromass carbon stock is not consistent. A comprehensive terminology that is compatible with IPCC definitions for avoiding misunderstanding is proposed. The proposal focuses on the use of the term necromass and is based on the position (standing, downed, or buried in soil) and size (length and diameter) of the pieces.

We recommend measuring fine woody necromass separately from coarse woody necromass and non-woody due to its specific characteristics spatial distribution.

Lower tier inventories may be based on published and generic default values. However, more uncertain and site-specific methods are required for accurate local and regional inventories.

Further research on the subject should be supported to develop more robust, accurate and cost-effective methods applied to measure forest carbon necromass.

\section{REFERENCES}

ARATO, H.D.; MARTINS, S.V.; FERRARI, S.H.S. Produção e decomposição de serapilheira em um sistema agroflorestal implantado para recuperação de área degradada em Viçosa-MG. Revista Árvore, v. 27, n. 5, p. 7I5-72I, 2003.

ARYAL, D.R.; DE JONG, B.H.J.; OCHOA-GAONA, S.; ESPARZA-OLGUIN, S.; MENDOZA-VEJA, J. Carbon stocks and changes in tropical secondary forests of southern Mexico. Agriculture, Ecosystems and Environment, v. 195, p. 220-230, 2014.

BERG, B.; MCCLAUGHERTY, C. Plant Litter - Decomposition, Humus Formation, Carbon Sequestration. 3 ed. Springer, 2014. 338p. 
BROWN JK. Handbook for inventorying downed woody material. Ogden. USDA Forest Service, 1974. 24 p.

BROWN, S. Measuring carbon in forests: current status and future challenges. Environmental Pollution, v. II6, n. 3, p. 363-372, 2002.

BRUNNER, I.; BAKKER, M.R.; BJÖRK, R.G.; HIRANO, Y.; LUKAC, M.; ARANDA, X.; BØRJA, I.; ELDHUSET, T.D.; HELMISAARI, H.S.; JOURDAN, C.; KONÔPKA, B.; LÓPEZ, B.C.; MIGUEL PÉREZ, C.; PERSSON, H.; OSTONEN, I. Fine-root turnover rates of European forests revisited: an analysis of data from sequential coring and ingrowth cores. Plant Soil, v. 362, p. 357-372, 2013.

BUSING, R.T.; WHITE, R.D.; HARMON, .M.E.; WHITE, M.E. Hurricane disturbance in a temperate deciduous forest: patch dynamics, tree mortality, and coarse woody detritus. Plant Ecology, v. 20I, n. I, p. 35I-363, 2008.

CAIRNS, M.A.; BROWN, S.; HELMER, E.H.; BAUMGARDNER, G.A. Root biomass allocation in the world's upland forests. Oecologia, v. I II, n. I, p. I-II, 1997.

CALDEIRA, M.V.W; VITORINO, M.D.; SCHAADT, S.S.; MORAES, E.; BALBINOT, R. Quantificação de serapilheira e de nutrientes em uma Floresta Ombrófila Densa. Semina: Ciencias Agrárias, v. 29, n. I, p. 53-68, 2008.

CHAMBERS, J.Q.; HIGUCHI, N.; SCHIMEL, J.P.; FERREIRA, L.V.; MELACK J.M. Decomposition and carbon cycling of dead trees in tropical forests of the central Amazon. Oecologia, v. 122, p. 380-388. 2000.

CHAO, K.J.; PHILLIPS, O.L.; BAKER, T.R.; PEACOCK, J.; LOPEZ-GONZALEZ, G.; MARTÍNEZ, R.V.; MONTEAGUDO, A.; TORRES-LEZAMA, A. After trees die: quantities and determinants of necromass across Amazonia. Biogeosciences, v. 6, p. 1615-1626. 2009.

CHAVE, J.; COOMES, D.A.; JANSEN, S.; LEWIS, S.L.; SWENSON, N.G.; ZANNE, A.E. Towards a worldwide wood economics spectrum. Ecology Letters, v. 12, p. 35I366. 2009.

CHOJNACKY, D.; AMACHER, M.; GAVAZZI, M. Separating duff and litter for improved mass and carbon estimates. Southern Journal of Applied Forestry, v. 33, n. I, p. 29-34, 2009.

DUCEY, M.J.; JORDAN, G.J.; GOVE, J.H.; VALENTINE, H.T. A practical modification of horizontal line sampling for snag and cavity tree inventory. Canadian Journal of Forest Research, n. 32, p. I217-1224, 2002.

EATON, J.M.; LAWRENCE, D. Woody debris stocks and fluxes during succession in a dry tropical forest. Forest Ecology and Management, v. 232, v. I-3, p. 46-55, 2006.

FAO (Food and Agriculture Organization of United Nations, IT). Global Forest Resources Assessment 2010. Forestry Department, 2010.340 p.
FONSECA, W.; REY BENAYAS, J.M.; ALICE, F.E. Carbon accumulation in the biomass and soil of different aged secondary forests in the humid tropics of Costa Rica. Forest Ecology and Management, v. 262, n. 8, p. I400-I408, 20 I I.

FONSÊCA, N.C.; MEUNIER, I.M.J.; SILVA, A.C.B.L. Evaluation of the Plant Necromass Component: Methodological Approaches and Estimates in Atlantic Forest, Northeast Brazil. Floresta e Ambiente, v. 26, n. 3, e20180383. 2019.

GESSNER, M.O.; SWAN, C.M.; DANG, C.K.; MCKIE, B.G.; BARDGETT, R.D.; WALL, D.H.; HÄTTENSCHWILER, S. Diversity meets decomposition. Trends in Ecology and Evolution, v. 25, n. 6, p. 372-380, 2010.

GIULIETTI, A.M.; BOCAGE NETA, A.L.; CASTRO, A.A.J.F; VIRGINIO, J.F.; SAMPAIO, E.V.S.B. Diagnóstico da vegetação nativa do Bioma Caatinga, 2003. 44p.

GODINHO, T.O.; CALDEIRA, M.V.W.; ROCHA, J.H.T.; CALIMAN, J.P.; TRAZZI, P.A. Quantificação de biomassa e nutrientes na serapilheira acumulada em trecho de Floresta Estacional Semidecidual Submontana, ES. Cerne, v. 20, n. I, p. II-20, 2014.

GOUGH, C.M.; VOGEL, C.S.; KAZANSKI, C.; NAGEL, L.; FLOWER, C.E.; CURTIS, P.S. Coarse woody debris and the carbon balance of a north temperate forest. Forest Ecology and Management, v. 244, n. I-3, p. 60-67, 2007.

HARMON, M.E.; FRANKLIN, J.F;; SWANSON, F.j.; SOLLINS, P.; GREGORY, S.V.; LATTIN, J.D.; CUMMINS, KW. Ecology of Coarse Woody Debris in Temperate Ecosystems. In: Advances in Ecological Research. Elsevier I5:133-302, 1986.

HARMON, M.E.; WHIGHAN, D.F.; SEXTON, J.; OLMSTED, I. Decomposition and mass of woody detritus in the dry tropical forests of Northeast Yucatan Peninsula, Mexico. Biotropica, v. 27, n. 3, p. 305-316, 1995.

HARMON, M.E.; SEXTON, J. Guidelines for measurements of woody detritus in forest ecosystems. University of Washington, College of Forest Resources, 1996. 73 p.

HARMON, M.E.; KRANKINA, O .; YATSKOV, M.; MATTHEW, E. Predicting broad-scale carbon stock of woody detritus from plot-level data. In: Assessment Methods for Soil Carbon. New York: CRC Press, p. 533-553, 200 I.

HARMON, M.E.; WOODALL, C.W.; FASTH, B.; SEXTON, J. Woody Detritus Density and Density Reduction Factors for Tree Species in the United States: A Synthesis. Gen. Tech. Rep. NRS-29. U.S. Department of Agriculture, Forest Service, Northern Research Station, 2008. 84 p.

HARMON, M.E.; FASTH, B .; WOODALL, C.W.; SEXTON, J. Carbon concentration of standing and downed woody detritus: Effects of tree taxa, decay class, position, and tissue type. Forest Ecology and Management, v. 29I, p. 259-267, 2013.

IPCC (Intergovernmental Panel on Climate Change). 2003. Good Practice Guidance for Land Use, Land-Use Change and Forestry. Institute for Global Environmental Strategies (IGES). 
IPCC (Intergovernmental Panel on Climate Change). 2006 Guidelines for National Greenhouse Gas Inventories. Agriculture, Forestry and Other Land Use. Institute for Global Environmental Strategies (IGES).

JANISCH, J.E.; HARMON, M.E. Successional changes in live and dead wood carbon stores: implications for net ecosystem productivity. Tree Physiology, v. 22, n. 2-3, p. 77-89, 2002.

KELLER, M.; PALACE, M .; ASNER, G.P.; PEREIRA, R.J.; SILVA, J.N.M. Coarse woody debris in undisturbed and logged forests in the eastern Brazilian Amazon. Global Change Biology, v. 10, p. 784-795, 2004.

KENNEDY, D.M.; WOODS, J.L.D. The influence of coarse woody debris on gravel beach geomorphology. Geomorphology, v. 159-160, p. 106-II5, 2012.

KLEINPAUL, I.S. Suficiência amostral para coletas de serapilheira acumulada sobre o solo em Pinus elliottii Engelm, Eucalyptus sp. e floresta estacional decidual. Revista Árvore, v. 29, n. 6, p. 965-972, 2005.

KNAPP, E.E.; KEELEY, J.E.; BALLENGER, E.A.; BRENNAN, T.j. Fuel reduction and coarse woody debris dynamics with early season and late season prescribed fire in a Sierra Nevada mixed conifer forest. Forest Ecology and Management, v. 208, n. I-3, p. 383-397, 2005.

KÖHL, M.; STÜMER, W.; KENTER, B.; RIEDEL, T. Effect of the estimation of forest management and decay of dead woody material on the reliability of carbon stock and carbon stock changes - A simulation study. Forest Ecology and Management, v. 256, n. 3, p.229-236, 2008.

KOSTEL-HUGHES. F; YOUNG, T.P.; CARREIRO, MM. Forest leaf litter quantity and seedling occurrence along an urbanrural gradient. Urban Ecosystems, v. 2, p. 263-278, 1998.

LIMA, S.S.; LEITE, L.F.C.; AQUINO, A.M.; OLIVEIRA, F.C.; CASTRO, A.A.J.F. Serapilheira e teores de nutrientes em argissolo sob diferentes manejos no norte do Piauí. Revista Árvore, v. 34, n. I, p. 75-84, 2010.

MAAS, G. C. B. Compartimentaç ão do estoque de carbono em Floresta Ombrófila Mista. 20I5. I72 p. PhD thesis Universidade Federal do Paraná, Curitiba.

MÄKIPÄÄ, R.; LINKOSALO, T. A non-destructive field method for measuring wood density of decaying logs. Silva Fennica, v. 45, n. 5 , p. I| $35-1 \mid 42,201$ I.

McCLAUGHERTY, C.A.; PASTOR, J.; ABER, J.D.; MELILLO, J.M. Forest litter decomposition in relation to soil nitrogen dynamics and litter quality. Ecology, v. 66, n. I, p. $266,1985$.

MOTA, M.C.; TOREZAN, J.M.D. Necromassa em reflorestamentos com espécies nativas da Mata Atlântica com 4 , 6 e 8 anos de implantação. Hoehnea, v. 40, n. 3, p. 499-505, 2013.
MOTTA, R. BERRETTI, R.; LINGUA, E.; PIUSSI, P. Coarse woody debris, forest structure and regeneration in the Valbona Forest Reserve, Paneveggio, Italian Alps. Forest Ecology and Management, v. 235, v. I-3, p. I55-163, 2006.

NORDÉN, B.; GÖTMARK, F; TÖNNBERG, M.; RYBERG, $M$. Dead wood in semi-natural temperate broadleaved woodland: contribution of coarse and fine dead wood, attached dead wood and stumps. Forest Ecology and Management, v. 194, n. I-3, p. 235-248, 2004.

PALACE, M.; KELLER, M.; ASNER, G. P.; SILVA, J. N. M.; PASSOS, C. Necromass in undisturbed and logged forests in the Brazilian Amazon. Forest Ecology and Management, v. 238, n. I-3, p. 309-318, 2007.

PASHER, J.; KING, D.J. Mapping dead wood distribution in a temperate hardwood forest using high resolution airborne imagery. Forest Ecology and Management, v. 258, n. 7, p. I536-|548, 2009.

PEARSON, T.R.H.; BROWN, S.L.; RAVINDRANATH, N. Integrating carbon benefit estimates into GEF projects, UNDP GEF Capacity Development and Adaptation Group Guidelines, 2005. 57 p.

PEARSON, T.R.H.; BROWN, S.L.; BIRDSEY, R.A. Measurement Guidelines for the Sequestration of Forest Carbon, United States Department of Agriculture - Forest Service. Delaware, 2007. 42 p.

PÉLLICO NETTO, S.; PELISSARI, A. L.; RIBEIRO, A.; MACHADO S. A.; NASCIMENTO, R. G. M. Sampling system for estimating woody debris in an urban mixed tropical forest. Anais da Academia Brasileira de Ciências, v. 90, n.4, p. 3769-3780, 2018

PIETRO-SOUZA, W.; CÂNDIDO, A.K.A.A.; FARIAS, L.N.; SILVA, N.M.; BARBOSA, D.S. Produção de necromassa e de serapilheira em área de preservação permanente pertencente ao Rio São Lourenço, Campo Verde - MT. Engenharia Ambiental, v. 9, n. I, p. 47-66, 2012

POLO, J.A.; HALLGREN, S.W.; LESLIE, D.M. Effect of longterm understory prescribed burning on standing and down dead woody material in dry upland oak forests. Forest Ecology and Management, v. 29I, p. I28-135, 2013.

PRESTON, C.M.; BHATTI, J.S.; FLANAGAN, L.B.; NORRIS, C. Stocks, chemistry, and sensitivity to climate change of dead organic matter along the canadian boreal forest transect case study. Climatic Change, v. 74, n. I-3, p. 223-25I, 2006.

AVINDRANATH, N.H.; OSTWALD, M. Carbon Inventory Methods, Handbook for Greenhouse Gas Inventory, Carbon Mitigation and Roundwood Production Projects. Advances in Global Change Research. Springer Science + Business Media B.V, 2008. 304 p.

RESH, S.C.; BATTAGLIA, M.; WORLEDGE, D.; LADIGES, S. Coarse root biomass for eucalypt plantations in Tasmania, Australia: sources of variation and methods for assessment. Trees - Structure and Function, v. I 7, n. 5, p. 389-399, 2003. 
RIBEIRO, A.; PÉLLICO NETTO, S.; STALL, D.; LEÃO, R.A.; NASCIMENTO, F.A.F. Proposta metodológica para realização de um inventário florestal de necromassa: um estudo de caso. Scientia Forestalis, v. 40, n. 93, p. 121-127, 2012.

SANQUETTA, M.N.I.; SANQUETTA, C.R.; CORTE, A.P.D; MOGNON, F; MENDONÇA, V.C. Teores de carbono e densidade básica da madeira de Cryptomeria japonica (Thunb. ex L. f.) D. Don em povoamentos no município de Rio Negro - PR. Enciclopédia Biosfera, v. 9, n. 17, p. 2450-2458, 2013.

SANTOS, S.L.; VÁLIO, I.F.M. Litter accumulation and its effect on seedling recruitment in a Southeast Brazilian Tropical Forest. Revista Brasileira de Botânica, v. 25, n. I, p. 89-92, 2002.

SATO, Y.; KUMAGAI, T.; KUME, A.; OTSUKI, K.; OGAWA, S. Experimental analysis of moisture dynamics of litter layers? The effects of rainfall conditions and leaf shapes. Hydrological Processes, v. 18, n. 16, p. 3007-3018, 2004.

SCHLESINGER, W.H.; LICHTER, J. Limited carbon storage in soil and litter of experimental forest plots under increased atmospheric CO2. Nature, v. 4I I, n. 6836, p. 466-469, 200 I.

SFB (Serviço Florestal Brasileiro). 20l4. Manual de Campo. Procedimentos para Coleta de Dados Biofísicos e Socioambientais, Inventário Florestal Nacional - Brasil. Brasília.

SMITH, J.E.; HEATH, J.S. A Model of Forest Floor Carbon Mass for United States. Forest Types, USDA Forest Service, 2002.

STOKLAND, J.N.; SIITONEN, J.; JONSSON, B.G. Biodiversity in Dead Wood, New York: Cambridge University Press. 2012.

STRAND L. 1958. Sampling for volume along a line. Medd Nor Skogforsok 5I: 327-33I.

SWEENEY, O.F.M.D.; MARTIN, R.D.; IRWIN, S.; KELLY, T.C.; O'HALLORAN, J.; WILSON, M.W.; McEVOY, P.M. A lack of large-diameter logs and snags characterises dead wood patterns in Irish forests. Forest Ecology and Management, v. 259, n. I0, p. 2056-2064, 2010.

USDA (United States Department of Agriculture, US). 20I I. In: Forest inventory and analysis national core field guide: field data collection procedures for phase 3 plots, version 5.I. Department of Agriculture, Forest Service. 201 I.

VAN WAGNER, C.E. The line intersect method in forest fuel sampling. Forest Science, v. 14, n. I, p. 20-26, 1968.

VAN WAGNER, C.E. Practical aspects of the line intersect method, Petawawa National Forest Institute. Canadian Forestry Service. 1982.

VCS (Verified Carbon Standard). 2012. In: VCS Module VMD0023 Estimation of carbon stocks in the litter pool. Version I.0. Sectoral Scope 14. The Earth Partners LLC.
VIEIRA, S. A; ALVES, L. F; DUARTE-NETO, P. J.; MARTINS, S. C.; VEIGA, L. G.; SCARANELLO, M. A.; PICOLLO, M. C.; CAMARGO, P. B.; CARMO, J. B. DO; NETO, E. S.; SANTOS, F. A. M., JOLY, C. A.; MARTINELLI, L. A. Stocks of carbon and nitrogen and partitioning between aboveand belowground pools in the Brazilian coastal Atlantic Forest elevation range. Ecology and Evolution, v. I, n. 3, p. $421-34,2011$.

WARREN, W.G. Line intersect sampling: an historical perspective. In: State-of-the-art methodology of forest inventories, 1990. p. 33-38.

WARREN, W.G.; OLSEN, P.F. A line intersect technique for assessing logging waste. Forest Science, v. 10, n. 3, p. 267276, 1964.

WATZLAWICK, L.F.; CALDEIRA, M.V.W.; VIERA, M.; SCHUMACHER, M.V.; GODINHO, T.O.; BALBINOT, R. Estoque de biomassa e carbono na Floresta Ombrófila Mista Montana Paraná. Scientia Forestalis, v. 40, n. 95, p. 353-362, 2012.

WEGGLER, K.; DOBBERTIN, M.; JÜNGLING, E.; KAUFMANN, E.; THÜRIG, E. Dead wood volume to dead wood carbon: the issue of conversion factors. European Journal of Forest Research, v. I3I, n. 5, p. |423-|438, 2012.

WOLDENDORP, G.; KEENAN, R.J.; BARRY, S.; SPENCER, R.D. Analysis of sampling methods for coarse woody debris. Forest Ecology and Management, v. I 98, p. I33- I48, 2004.

WOOD, T.E.; LAWRENCE, D.; CLARK, D.A. Variation in leaf litter nutrients of a Costa Rican rain forest is related to precipitation. Biogeochemistry, v. 73, n. 2, p. 4I7-437, 2005.

WOODALL, C.; WILLIAMS, M.S. Sampling Protocol, Estimation, and Analysis Procedures for the Down Woody Materials Indicator of the FIA Progam. United States Department of Agriculture, Forest Service. Internal report. Forest Inventory and Analysis. General Technical Report NC-256. 2007.

WOODALL, C.W.; RONDEUX, J.; VERKERK, P.j.; STÅHL, G. Estimating dead wood during national forest inventories: a review of inventory methodologies and suggestions for harmonization. Environmental Management, v. 44, n. 4, p. 624-3I, 2009.

WOODALL, C.W.; WALTERS, B.F.; OSWALT, S.N.; DOMKE, G.M.; TONEY, C.; GRAY, A.N. Biomass and carbon attributes of downed woody materials in forests of the United States. Forest Ecology and Management, v. 305, p. 48-59, 2013.

ZHANG, C.; JAMIESON, R.C.; MENG, F; GORDON, R.J.; BHATTI, J.; BURQUE, C.P. Long-term forest-floor litter dynamics in Canada's boreal forest: Comparison of two model formulations. Ecological Modelling, v. 222, n. 6, p. |236-|244, 201।. 